九州大学学術情報リポジトリ

Kyushu University Institutional Repository

\title{
Antifungal Substances Produced by Cephalothecium roseum Corda
}

Maekawa, Kazuyuki

Laboratory of Pesticide Chemistry, Faculty of Agriculture, Kyushu University

Taniguchi, Eiji

Laboratory of Pesticide Chemistry, Faculty of Agriculture, Kyushu University

Watanabe, Takahide

Laboratory of Pesticide Chemistry, Faculty of Agriculture, Kyushu University

https://doi.org/10.5109/22825

出版情報：九州大学大学院農学研究院紀要. 17 (2)，pp.137-141，1973-03. Kyushu University バージョン：

権利関係 : 
J. Fac. Agr., Kyushu Univ., 17, 137-141 (1973)

\title{
Antifungal Substances Produced by Cephalothecium roseum Corda
}

\author{
Kazuyuki Maekawa, Eiji Taniguchi and Takahide Watanabe \\ Laboratory of Pesticide Chemistry, Faculty of Agriculture, \\ Kyushu University, Fukuoka
}

(Received July 2, 1972)

\begin{abstract}
No antifungal activity could be recognized in the acidic or basic fractions obtained from the culture filtrate of Cephalothecium roseum Corda, which was not in accordance with Yoshii's description. The active substances were found only in ether soluble neutral fraction. A major antifungal substance of them, $\mathrm{C}_{19} \mathrm{H}_{21} \mathrm{O}_{5}$ was identified as trichothecin.
\end{abstract}

From a culture filtrate of Cephalothecium roseum Corda which was isolated from wheat stems provided as package materials, H. Yoshii obtained, in 1945, a pale yellow crystalline antifungal acidic substance (m. p. $124-6^{\circ} \mathrm{C}$ ) which inhibited the germination of spores of Piricularia oryzae, Cochliobolus miyabeanus etc. and the development of mycelia of $\mathbf{1 2 6}$ phyto-pathogenic fungi, and he named it Cephalothecin (Yoshii, 1957).

At about the same time, Freeman et al. obtained an antifungal substance, Trichothecin (m. p. 116- $8^{\circ} \mathrm{C}$ ) from Trichothecium roseum Link isolated from diseased tomatoes (Freeman, 1955 ; Freeman and Gill, 1950 ; Freeman, Gill and Waring 1959 ; Freeman and Morrison, 1948, 1949). The chemical structure of trichothecin was finally established by Gutzwiller et al., (1964).

According to Freeman, Trichothecium roseum Link and Cephalothecium roseum Corda are identical. However, as there are some differences in the descriptions between cephalothecin and trichothecin, the present study was undertaken in order to elucidate the structure of cephalothecin, from a generous supply of the stocked strain of Cephalothecium roseum Corda.

\section{EXPERIMENTALS}

\section{(1) Culture}

The culture of Cephalothecium roseum Corda was carried out according to Yoshii's description. Namely, the culture medium used was half the amount of the Richard-medium type and corn steeped liquor was added to produce a $\mathbf{0 . 5}$ of solution which was finally adjusted to pH 5.5 with $0.1 \mathrm{~N} \mathrm{NaOH}$. After inoculating the strain, it was allowed to stand at $25^{\circ} \mathrm{C}$ for 20 days.

In one week, mycelia covered the surface of the medium; in about 10 days the surface of mycelia became orange owing to the formation of spores; and in 20 days $\mathrm{pH}$ of the medium became 8.0-9.0. 


\section{(2) Bioassay}

So as to evaluate the isolation procedure two methods of bioassay were conducted.

(i) Culture method on a slide glass described by Yoshii (1957) : -On a hole slide glass, the sample and spores of fungus to be tested (usually Aspergillus $n i$ ger) were mixed and incubated at $25^{\circ} \mathbf{C}$. In 24 hours the germination of spores was observed microscopically.

(ii) Biochromatography devised by the authors: - One half of a developed and air dried TLC (silica gel) was visualized by a suitable spraying reagent such as vanillin sulfuric acid. The other half of the TLC was sprayed with melted hot culture medium containing agar, then sprayed with spores suspension of testing fungus, and thereafter incubated at $25^{\circ} \mathrm{C}$ for 48 hours. The positions containing antifungal substances were located as white spots on a black ground due to germination of spores (Fig. 1).

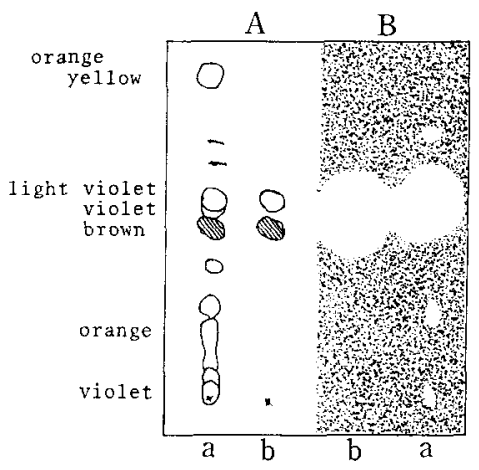

Solvent, Benzene : Ethyl acetate $=5: 1$

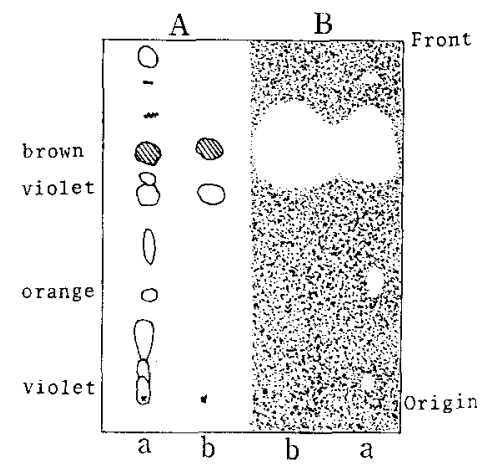

Solvent, Petr. ether : ether

a, Ether extract of the culture filtrate

b, Trichothecin

A, Visualized by vanillin sulfuric acid

B, Agar and spores of Aspergillus niger were sprayed

Fig. I. Biochromatograms of antifungal substances produced by Cephalothecium roseum Corda.

\section{(3) Thin layer chromatography (TLC)}

TLC was carried out by using silica gel. Benzene: ethylacetate (5: 1) and petroleum ether : ether (1: 2) were suitable as the developing solvent, and chromatograms were visualized by spraying with vanillin sulfuric acid or alkaline permanganate solution.

\section{(4) Isolation and Identification}

The extraction and purification were at first performed according to Yoshii's description. However, no antifungal activity could be recognized in the acidic or basic fractions of the culture filtrate and mycelia. The active substance(s) was found only in ether soluble neutral fraction (Fig. 2). 
Culture broth of Cephalothecium roseum Corda

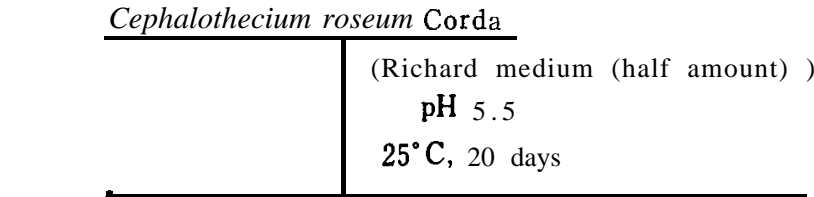

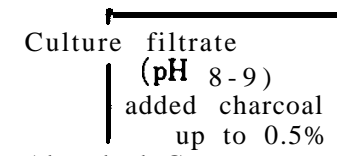

Absorbed C

up to $0.5 \%$

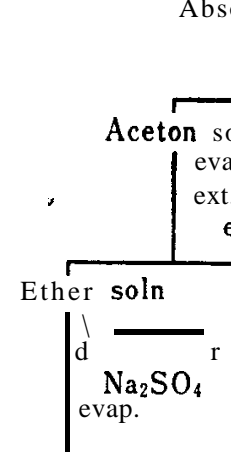

Crude prepn. (I)

(yield $0.35 \mathrm{~g} / 1$ )

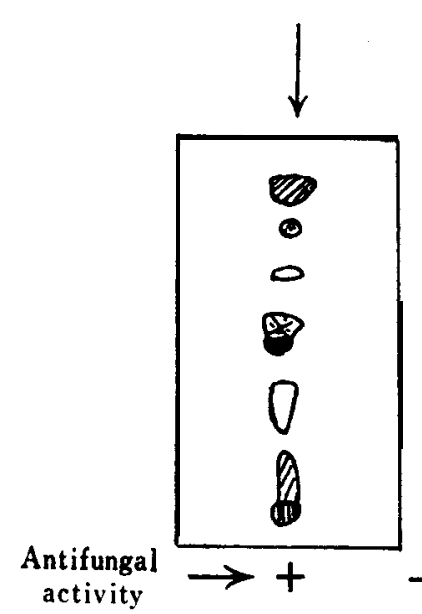

ext. with $5 \% \mathrm{NaOH}$

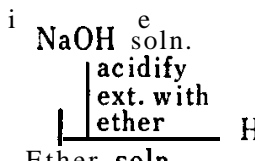

Ether soln.

$$
\text { acetone }
$$

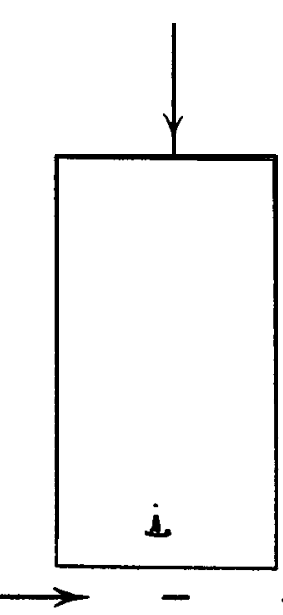

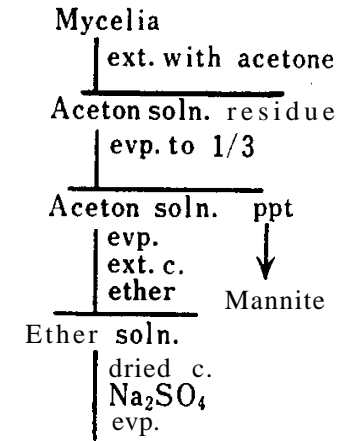

Crude prepn. (II) (yield, $3.6 \mathrm{~g} / 100 \mathrm{~g}$ ) mycelia

Solvent ; benzene : ethylacetate (5:1)

Oyellow, (11 blue, @violet, @orange brown, @gray,

black, $\theta$ brown black.

Fig. 2. Isolation procedure of the antifungal metabolite from Cephalothecium roseum Corda.

In order to confirm this fact the crude ether extract was repeatedly washed with $5 \% \mathrm{NaOH}$ aq. solution. Nevertheless, the active substance did not transfer to the alkaline solution.

On the whole no acidic antifungal substances could be found. This result 
might be ascribed to the fact that the strain mutated during long storage (over 15 years) or to some other facts.

Therefore, the investigation for the ether soluble fraction was continued. A major antifungal substance (Rf 0.53 on silica gel TLC; solvent, benzene : ethylacetate $=5: 1$ ) was repeatedly purified by TLC and finally a crystalline substance of m. p. $118^{\circ} \mathrm{C}$ and of $\mathrm{C}_{19} \mathrm{H}_{21} \mathrm{O}_{5}$ was obtained.

$$
\begin{array}{r}
\mathrm{C}_{19} \mathrm{H}_{24} \mathrm{O}_{5}: \text { Calcd. C, } 68.65 \% \mathrm{H}, 7.28 \% \\
\text { Found C, } 68.32 \% \mathrm{H}, 7.42 \%
\end{array}
$$

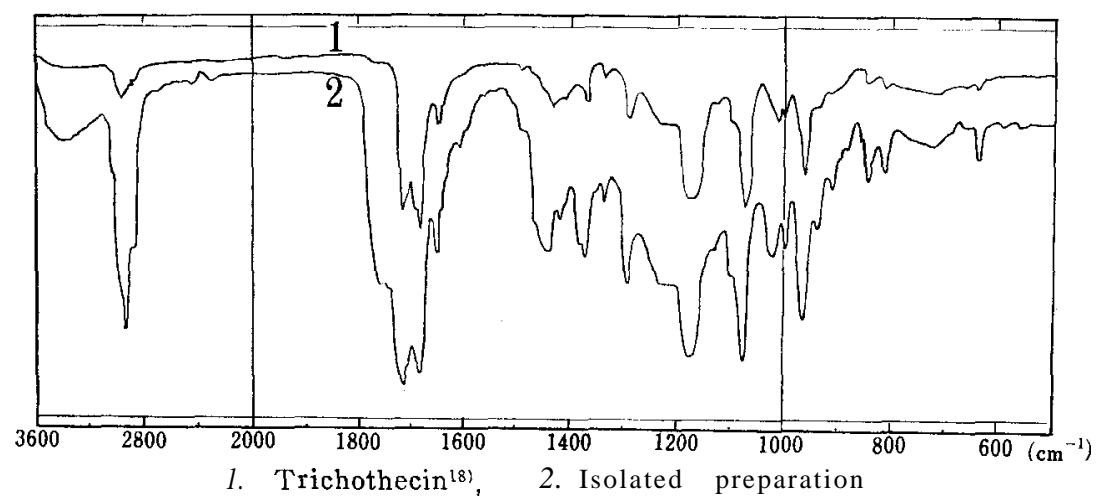

Fig. 3. IR spectra of the preparation isolated from Cephalothecium roseum Corda and of trichothecin.

This substance was identified as trichothecin by co-chromatography (Rf, activity and brown coloration by vanillin-sulfuric acid), IR-spectrum (Fig. 3) (Freeman, Gill and Waring, 1959), (Yamamoto, Henmi and Yamano 1969) and mixed melting point.

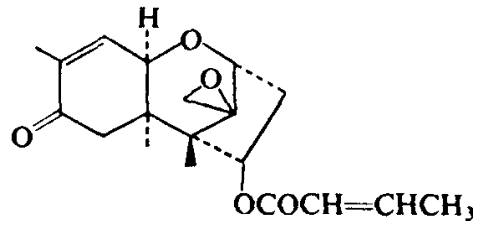

Trichothecin

As shown in Fig. 1, there are two minor antifugal substances (Rf 0.75 and 0.25 on TLC, by solvent, benzene: ethylacetate $=5: 1$ ).

When Trichothecium roseum was grown on surface culture on a Czapek-Doxammonium tartrate: corn steeped liquor medium for 4 weeks, the major metabolites were rosenonolactone (Harris, Robertson and Whalley, 1958), (Robertson, Smithies and Tittensor, 1949) and rosololactone [Harris, Robertson and Whalley, 1958). Desoxyrosenonolactone (Whalley, Green, Arigoni, Britt and Djerassi, 1959),6ßhydroxyrosenolactone (Allison, Connolly and Overton, 1968), (Holzapfel and Steyn, 1968) and trichothecin (Fishman, Jones, Lowe and Whiting, 1960), (Freeman, Gill and Waring, 1959), (Godtfredsen and Vangedal, 1964), (Jones and Lowe, 1960) were isolated in smaller amounts. 
Furthermore, B. Achilladelis et al. (1969) isolated rosenololactone and crotocin. Similarly, it had already been reported that several related antifungal compounds were isolated.

Two minor substances observed on TLC remained for a further elucidation.

\section{ACKNOWLEDGEMENT}

The authors are indebted to Prof. Dr. T. Asada, Ehime University for kindly supplying the stocked strain, and to Dr. K. Nakazawa, Takeda Pharmaceutical Co. for a sample of trichothecin.

\section{REFERENCES}

Achilladelis, B. and J. R. Hanson 1969 Minor terpenoids of Tricothecium roseum. Phytochem., 8, 765

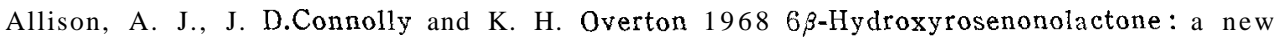
metabolite from Trichothecium roseum Link. J. Chem. Soc. (C), 21 '22

Fishman, J., E. R. H. Jones, G. Lowe and M, C. Whiting 1960 The chemistry and stereochemistry of trichothecin. J. Chem. Soc., 3948

Freeman, G. G. 1955 Further biological properties of trichothecin, an antifungal substance from Trichothecium roseum Link, and its derivatives. J. gen. Microbiol., 12, 213

Freeman, G. G. and J. E. Gill 1955 Alkaline hydrolysis of trichothecin. Nature, 166, 698

Freeman, G. G. and R. I. Morrison 1948 Trichothecin, an antifungal metabolic product of Trichothecium roseum Link, Nature, 162, 30

1949 The isolation and chemical properties of trichothecin, an antifungal substance from Trichothecium roseum Link. Biochem. J., 44. 1

Freeman, G. G., J. E. Gill and W. S. Waring 1959 The structure of trichothecin and its hydrolysis products. J. Chem. Soc., 1105

Freeman, G. G., R. I. Morrison and S. E. Michael 1949 Metabolic products of Trichothecium roseum Link. Biochem. J., 45, 191

Godtfredsen, W. 0. and S. Vangedal 1964 Trichodermin, a new antibiotic, related to trichothecin, Proc. Chem. Soc., 188

Gutzwiller, J., R. Mauli, H. P. Sigg and Ch. Tamm 1964 Die Konstitution von Verrucarol und Roridin C. Helv. Chim. Acta, 47, 2234

Harris, A., A. Robertson and W. B Whally 1958 The chemistry of fungi, part 31, The structure of rosenonolactone. J. Chem. Soc., 1799

3958 The chemistry of fungi, part 32, Rosololactone, a metabolite of Trichothecium roseum Link. J. Chem. Soc., 1807

Holzapfel, C. W. and P. S. Steyn 1968 The isolation and structure of a new diterpene lactone from Trichothecium roseum Link. Tetrahedron, 24, 3321

Jones, E. R. H. and G. Lowe 1960 The biogenesis of trichothecin. J. Chem. Soc., 39.59

Robertson, A., W. R. Smithies and E. Tittensor 1949 Rosenonolactone from Trichothecium roseum Link. J. Chem. Soc., 879

Whalley, W. B., B. Green, D. Arigoni, J. J. Britt and C. Djerassi 1959 The absolute configuration of rosenonolactone and related diterpenoid. J. Amer. Chem. SOC., 81, 5520

Yamamoto, I., T. Henmi and T. Yamano 1969 Sesquiterpenoid antibiotics from molds. Ann. Rept. Takeda Res. Lab., 28, 69

Yoshii, H. 1957 Studies on the disease resistance in rice plants. Mem. Ehime Univ., sect. VI (Agric) 3, 1 